Abstracta Iranica Abstracta Iranica

Revue bibliographique pour le domaine irano-aryen

Volume 31 | 2011

Comptes rendus des publications de 2008

\title{
«Weights and Measures in Qajar Iran ». Studia Iranica 37/1, 2008, p. 57-115.
}

\section{Christoph Werner}

\section{(2) OpenEdition}

1 Journals

\section{Édition électronique}

URL : http://journals.openedition.org/abstractairanica/39387

DOI : 10.4000/abstractairanica.39387

ISSN : 1961-960X

Éditeur :

CNRS (UMR 7528 Mondes iraniens et indiens), Éditions de l'IFRI

Édition imprimée

Date de publication : 15 mai 2011

ISSN : 0240-8910

Référence électronique

Christoph Werner, « «Weights and Measures in Qajar Iran ». Studia Iranica 37/1, 2008, p. 57-115. », Abstracta Iranica [En ligne], Volume 31 | 2011, document 148, mis en ligne le 11 octobre 2012, consulté le 28 septembre 2020. URL : http://journals.openedition.org/abstractairanica/39387 ; DOI : https:// doi.org/10.4000/abstractairanica.39387

Ce document a été généré automatiquement le 28 septembre 2020.

Tous droits réservés 


\section{« Weights and Measures in Qajar Iran ». Studia Iranica 37/1, 2008, p.} 57-115.

\section{Christoph Werner}

1 This substantial contribution is a highly welcome handlist of the most common weights and measures to be encountered in sources from the Qajjār period. As the author rightly states, it adds considerably to the German classic by Walther Hinz. After an initial discussion of difficulties involved in compiling such a compendium, the sources used and a recapitulation of the first major attempt to unify measures and weights in 1935, we find alphabetically arranged compilations, meticulously annotated, and divided along three lines: length, surface and weight.

2 Note that some of the expressions and terms appear in more than one list and are used quite differently. Thus ša ìr can denote a measure of length (as one third of an inch), but is also frequently used as a square measure of cultivated land (then 416 square meters). One can easily see that in some cases a regional bias exists, thus information given in one European source on Gilan might not correspond to usages elsewhere. In most instances, however, one will be comforted to know simply that one is indeed dealing with a term of measurement (the information in standard dictionaries, even in the Logat-nāme-ye DehHodā beinigverylimited). Ideally, these lists should be augmented and commented upon by other researchers.

\section{INDEX}

Thèmes : 4.2.1. Safavides et Qâjârs 
AUTEURS

CHRISTOPH WERNER

Philipps-Universität - Marburg 